\title{
Trends and risks factors associated to women obesity in Cameroon and Gabon
}

\author{
Hénock Blaise Nguendo Yongsi ${ }^{1}$, Olivier Abondo Ngwa $^{2}$ \\ ${ }^{1}$ Geospatial land \&Health Research Group, Population and Health Dept, Institute for Training \& Research in Population Studies (IFORD), \\ University of Yaoundé II, Cameroon \\ ${ }^{2}$ Care-IFA, Institute for Training \& Research in Population Studies (IFORD), University of Yaoundé II, Cameroon
}

Email address:

Sir_nguendoyongsi@hotmail.com (H. B. N. Yongsi)

\section{To cite this article:}

Hénock Blaise Nguendo Yongsi, Olivier Abondo Ngwa. Trends and Risks Factors Associated to Women Obesity in Cameroon and Gabon. American Journal of Health Research. Vol. 2, No. 6, 2014, pp. 420-428. doi: 10.11648/j.ajhr.20140206.26

\begin{abstract}
Overweight or obesity sets in when there is a successive increase in body mass. Obesity is quantified or measured using body mass index (BMI) which is calculated using the weight and size of an individual. If the BMI is greater than or equal to $25 \mathrm{~kg} / \mathrm{m}^{2}$, a person is considered to be overweight, which is a condition associated with excessive fat. The increase in body weight and its corollary (obesity) is a major public health problem, which is becoming increasingly important in developing societies. In Cameroon and Gabon, we note an increase in the proportion of overweight among women: nearly $2.77 \%$ between 2004 and 2011 (from Cameroon) and nearly 13.22\% between 2000 and 2012 (from Gabon). The objective of this study is to show that overweight women are going to become a public health problem in Central Africa. For this purpose, we decided to study the increased risk of becoming overweight for women in central Africa, namely in Cameroon and Gabon. We focused firstly, on the explanatory sources of the increase in the proportion of overweight women and secondly, the factors associated with the risk of being overweight among women from Gabon and Cameroon. This study is about women aged 15-49 years disseminated throughout the national territory of both countries. Results show that the increase in the proportion of overweight in women is mainly due to a change of lifestyle. The explanatory analysis model highlights that, area of residence, age, place of residence, the standard of living of household, marital status and occupation of women, parity (number of children) and educational level (only in Cameroon) are factors explaining weight increase in women. Therefore, medical and educational workers, as well as opinion leaders, need to educate women about the importance of sedentary lifestyle and the need to have a quality dietary habit and food hygiene (eat organic foods consisting mainly of fruits and vegetables).
\end{abstract}

Keywords: Overweight, Female Population, Behavior Effect, Composition Effect, Cameroon, Gabon

\section{Introduction}

Considered as excessive accumulation of adipose tissue, obesity is as result of imbalance between dietary intake and energy expenditure. An overweight individual has a Body Mass Index (BMI) greater than or equal to $25 \mathrm{~kg} / \mathrm{m}^{2}$ [11]. According to the latest surveys, more than half of adult populations $(50.3 \%)$ in the OECD states suffer from obesity. In some countries of the European Union, this proportion is even higher (55.8\%). According to WHO estimates, there are 1.6 billion obese adults and 400 million obese adults worldwide in 2005. In addition, we noted that between 1980 and 2005, the obesity rate has at least tripled in 2015 and there are estimates that approximately 2.3 billion adults will be overweight and more than 700 million will be obese.
Progressing in an endemic manner, in developed countries, this overweight phenomenon extends increasingly in developing countries, namely in Africa where progression can be superimposed to that of USA progressing with lag as the main difference $[10,11]$. In developing countries overweight is more evident among individuals in households with a higher standard of living while in developed societies, it is highly representative among individuals who have a low standard of living. [12]. Apart from differences related to the context of developed and developing countries, there are also differences related to individuals metabolic process. With respect to genetics, which plays a differential role in weight gain among individuals, some ethnic groups are more predisposed than others to develop saturation or lipolysis adiposities [1, 2, 9]. Studies associated to environmental factors, showed the excessive weight gain too. We can 
classify them in two groups: homogeneous-exogenous forces (which affect the population in a global and identical manner) and heterogeneous-exogenous forces (which differentially affect a particular segment of population) [13].

In Central Africa, although it also follows a sustained and differential growth depending on the country, the prevalence of obese women is already observed in the different age groups and specifically at the age of motherhood. In fact, the women aged between 15-49 years presented:

- In Cameroon, a prevalence of obese women was $29.40 \%$ in 2004 as compared to $32.17 \%$ in 2011 [7, 8];

- In Gabon, the prevalence of obese women was $25.22 \%$ in 2000 as compared to $38.44 \%$ in 2012 [3, 4].

This increase in the number of obese women $(2.77 \%$ in Cameroon between 2004 and 2011 and 13.22\% in Gabon between 2000 and 2012) occurs in diverse social, economic and health contexts.

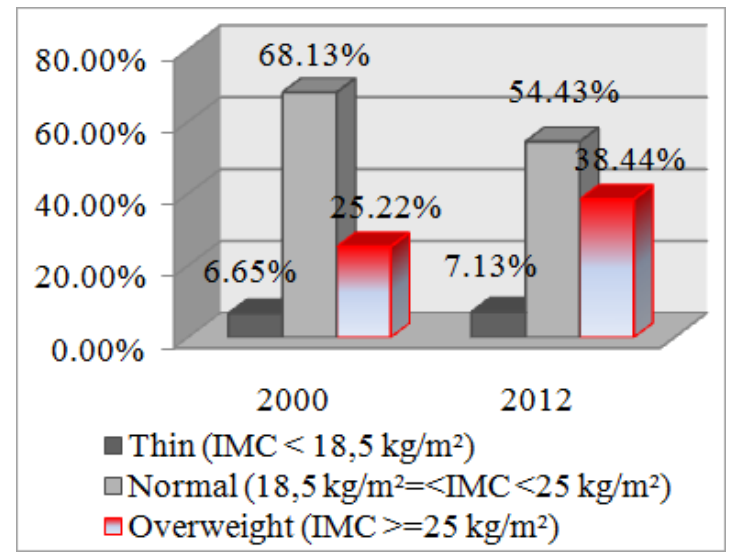

Source: EDSG 2000 and EDSG 2012

Figure 1. Proportion (\%) of women living weight of women in 2000 and 2012, Gabon

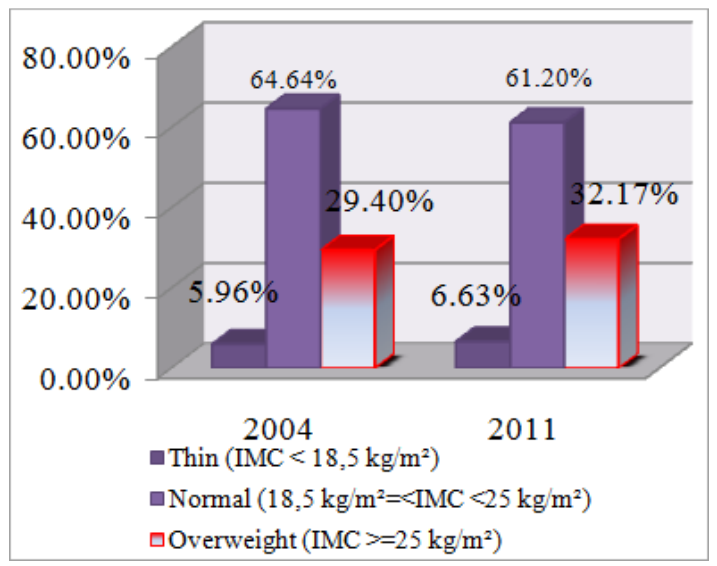

Source: EDS 2004 and EDS-MICS 2011

Figure 2. Proportion (\%) of weight state from women in 2004 and 2011, Cameroon.

Socially, few women are aware of the risks and consequences of overweight on health (risk of cardiovascular accidents, occurrence of type 2 diabetes, hypertension ...). This is the case of Cameroon where, there are only $3.2 \%$ of those who engage in regular sports activity [8]. Regarding the economic aspect, Cameroon observes a growth rate of Gross Domestic Production (GDP), which hovers around 5\% over the last five years [6]. Gabon, on the other hand, has a good macroeconomic performance supported by strong oil revenues (with almost $48 \%$ of GDP). This earned her the third position in Africa, as a "middle income country" according to international institutions [3]. However and in both countries we observe a king of feminization of poverty: women have a lower activity rate and are more populated in the rural areas than men. As concerns health, in 2011 nearly one out of three women $(32.17 \%)$ is overweight or obese in Cameroon. This indicator reached $46 \%$ in Yaounde / Douala [8]. While in Gabon, approximately $38.44 \%$ of women aged $15-49$ years present a status of overweight or obesity. In Libreville and Port-Gentil cities, this indicator reached $49.2 \%$ [3].

The objective of this study is to show that obesity among women is becoming a public health problem in Central Africa. For this purpose, we decided to study the risk of becoming overweight or obese among women in central Africa, especially in Cameroon and Gabon. We have chosen Cameroon and Gabon because in Central Africa, those two countries are socially and politically stable. This condition is too important for the study of social behavior. Therefore, we focused firstly, on the trend and the potential explanatory sources of the increase of obese women between 2004 and 2011 (Cameroon) and 2000 and 2012 (Gabon); and secondly, the factors which explain overweight among women in 2011 (Cameroon) and 2012 (Gabon).

\section{Material and Methods}

\subsection{Data Sources and Sample Selection}

Data used here derive from Demographic Health Surveys (DHS) conducted in Cameroon (2004 and 2011) and Gabon (2000 and 2012). Those database have been chosen because of (i) the availability of recent data on anthropometric parameters (weight and height) and (ii) the possibility of conducting an evolutionary study, the same statistical sampling method was used to select our sample [3, 4, 7, 8]. In Cameroon, the study was conducted on 5181 women (2004) and 7936 (2011) women between the ages 15-49 years and then extrapolated throughout Cameroon. In Gabon, the study was conducted on 6500 women in 2000 and 9000 in 2012 women between the ages 15-49 years and then extrapolated throughout the territory as well. The sample selection was made from a two-stage stratified sampling method. In the first stage, we randomly sampled the Enumerated Areas (EAs) after sorting the study frame by field respectively, according to place of residence, division and subdivision. And in each selected area, we had our second stage made up of households. These selected households were eligible for the survey of all women between the ages 15-49 who have lived in either of the countries before the passage of the investigating officer. Anthropometric measurements (weight and height) permitted the calculation of Body mass index $\left(\mathrm{BMI}=\right.$ weight $/$ height $\left.{ }^{2}\right)$. 


\subsection{Statistical Analysis}

Two methods were used for statistical analysis: the demographic decomposition [5] and logistic regression analysis model. The demographic decomposition helps to describe the primary reason for the increase in the proportion of obese women between 2004 and 2011 (Cameroon), 2000 and 2012 (Gabon). Two types of decomposition were carried out:

Simple decomposition has permitted us to investigate the contributions of effect of performance and composition. The effect of performance showed the contribution of social change which is attributable to the average change in the state of obesity at different social categories. Concerning the composition effect, it indicates how much change due to changes in the structure of female population, aged between 15 and 49 years old. Consider Y, the aggregate behavior of several sub-populations ( $\mathrm{y}$ j) with a relative number of these sub-populations ( $\mathrm{w} \mathrm{j}$ ); $\Delta \mathrm{Y}$ as the history of change of obese women $(\mathrm{Yt}+1-\mathrm{Yt})$; and $\mathrm{Y}^{-}$the national average between two periods of overweight.

$$
\bar{Y}=\left(Y_{t 1}+Y_{t}\right) / 2
$$

with $Y_{t}=\sum w_{j t} * y_{j t}$

$$
\Delta Y=\sum \bar{y}_{j} * \Delta w_{j}+\sum \bar{w}_{j} * \Delta y_{j}
$$

Advanced decomposition unravels the effect of performance into three sub-components: the contribution of the basic nutritional system from Cameroon (basic performance) the contribution related to the differentiation of overweight according to the categories of the classification variables (differentiation effect) while the contribution associated with the classification variables is not taken into account in the decomposition (residual effect).

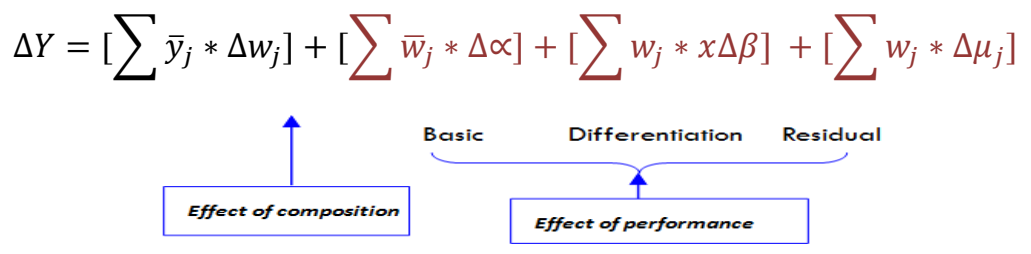

The binary logistic regression model permitted us to perform an analysis of causal effects of women with an overweight status.

\section{Results}

\subsection{Evolution of Overweight Women in Cameroon (between 2004 and 2011) and Gabon (between 2000 and 2012)}

This study was carried out using some socio-cultural and economic categories as presented below.

\subsubsection{Age Groups}

The ages of women were segmented into 3 sub-groups during analysis: $15-24$ years, 25-34 years and 35-49 years
(Tables I and II). The results of simple decomposition revealed that the increase in the number of obese women is mainly due to an effect of performance; $87.39 \%$ and $84.96 \%$ in Gabon and Cameroon respectively. Furthermore, we found that this effect is greater between the ages 35-49 years compared to other age group. The extension of performance's effect shows that the main source of change is the effect of differentiation in Gabon (121.76\%) and the residual's effect in Cameroon (161.21\%). This indicates that, the differential change in women behavior is the main source of increase in the number of obese women in Gabon. In Cameroon, the main source of explanatory behavior change, associated with the increase in the proportion of the condition of overweight women, is as a result of other variables not considered here.

Table 1. Simple and advanced decompositions of the increase in the proportion of overweight women by age group (Gabon).

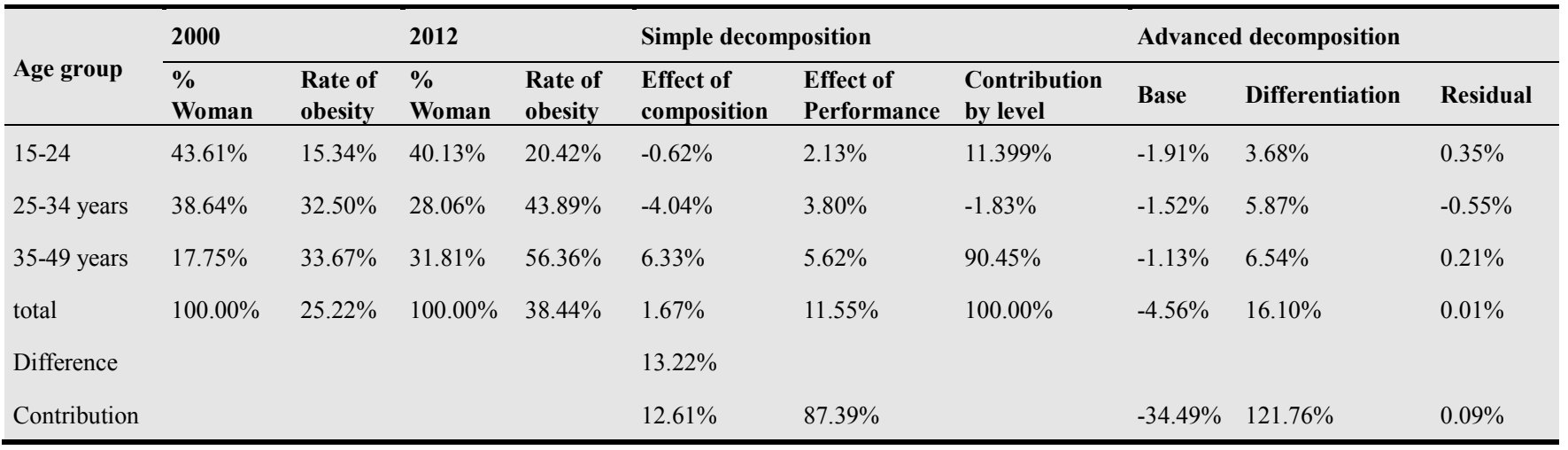


Table 2. Simple and advanced decompositions of the increase in the proportion of overweight women by age group (Cameroon).

\begin{tabular}{|c|c|c|c|c|c|c|c|c|c|c|}
\hline \multirow[b]{2}{*}{ Age group } & \multicolumn{2}{|l|}{2004} & \multicolumn{2}{|l|}{2011} & \multicolumn{3}{|c|}{ Simple decomposition } & \multicolumn{3}{|c|}{ Advanced decomposition } \\
\hline & $\begin{array}{l}\text { \% } \\
\text { Woman }\end{array}$ & $\begin{array}{l}\text { Rate of } \\
\text { obesity }\end{array}$ & \% Woman & $\begin{array}{l}\text { Rate of } \\
\text { obesity }\end{array}$ & $\begin{array}{l}\text { Effect of } \\
\text { composition }\end{array}$ & $\begin{array}{l}\text { Effect of } \\
\text { Performance }\end{array}$ & $\begin{array}{l}\text { Contribution } \\
\text { by level }\end{array}$ & Base & $\begin{array}{l}\text { Different } \\
\text { iation }\end{array}$ & Residual \\
\hline $15-24$ & $45.65 \%$ & $21.78 \%$ & $43.67 \%$ & $20.01 \%$ & $-0.41 \%$ & $-0.79 \%$ & $-43.42 \%$ & $0.39 \%$ & $-0.74 \%$ & $-0.44 \%$ \\
\hline $25-34$ & $29.69 \%$ & $31.79 \%$ & $30.05 \%$ & $36.98 \%$ & $0.12 \%$ & $1.53 \%$ & $60.47 \%$ & $0.26 \%$ & $-0.99 \%$ & $2.28 \%$ \\
\hline $35-49$ & $24.67 \%$ & $40.61 \%$ & $26.28 \%$ & $46.86 \%$ & $0.70 \%$ & $1.59 \%$ & $82.95 \%$ & $0.22 \%$ & $-1.26 \%$ & $2.63 \%$ \\
\hline total & $100.00 \%$ & $29.40 \%$ & $100.00 \%$ & $32.17 \%$ & $0.42 \%$ & $2.35 \%$ & $100.00 \%$ & $0.87 \%$ & $-2.98 \%$ & $4.47 \%$ \\
\hline Contribution & & & & & $15.04 \%$ & $84.96 \%$ & & $31.41 \%$ & $-107.71 \%$ & $161.21 \%$ \\
\hline
\end{tabular}

Sources: Treatment of EDSG 2004 and EDS-MICS 2011 data, Cameroon

\subsubsection{Residential Area}

In this study, residential area refers to the geographical environment in which the woman resides. The various administrative regions of Cameroon and Gabon were grouped into larger areas according to their similarities in terms of fauna, flora, tradition, culture, food, fashion and climate (Tables III and IV). In addition, big cities in both countries were grouped together for reliability. The results of simple decomposition in the increase of the proportion of obese women, by region of residence, highlight a preponderance of the effect of performance in explaining the increase in the number of obese women. This predominance of the performance's effect is mainly observed in the "South / East / Central / Littoral" regions of Cameroon (61.28\%) and the Western Region of Gabon (49.97\%). The extension of performance's effect shows that the main explanatory source of the increased number of obese women reveals a significant contribution of the basic effect in Gabon (94.10\%) and a strong contribution of differentiation's effect in Cameroon (160.14\%).

Table 3. Simple and advanced decompositions of the increase in the proportion of overweight women by residential area (Gabon).

\begin{tabular}{|c|c|c|c|c|c|c|c|c|c|c|}
\hline \multirow{2}{*}{$\begin{array}{l}\text { Residential } \\
\text { area }\end{array}$} & \multicolumn{2}{|l|}{2000} & \multicolumn{2}{|l|}{2012} & \multicolumn{3}{|c|}{ Simple decomposition } & \multicolumn{3}{|c|}{ Advanced decomposition } \\
\hline & $\begin{array}{l}\% \\
\text { woman }\end{array}$ & $\begin{array}{l}\text { Rate of } \\
\text { obesity }\end{array}$ & $\begin{array}{l}\% \\
\text { woman }\end{array}$ & $\begin{array}{l}\text { Rate of } \\
\text { obesity }\end{array}$ & $\begin{array}{l}\text { Effect of } \\
\text { composition }\end{array}$ & $\begin{array}{l}\text { Effect of } \\
\text { performance }\end{array}$ & $\begin{array}{l}\text { contribution } \\
\text { by level }\end{array}$ & Base & Differentiation & Residual \\
\hline $\begin{array}{l}\text { Libreville / } \\
\text { Port-gentil }\end{array}$ & $24.83 \%$ & $37.90 \%$ & $17.58 \%$ & $48.67 \%$ & $-3,14 \%$ & $2.28 \%$ & $-6.46 \%$ & $2.64 \%$ & $0.11 \%$ & $-0.46 \%$ \\
\hline North & $17.89 \%$ & $18.40 \%$ & $19.68 \%$ & $35.50 \%$ & $0.48 \%$ & $3.21 \%$ & $27.95 \%$ & $2.34 \%$ & $0.19 \%$ & $-0.68 \%$ \\
\hline East & $22.61 \%$ & $25.32 \%$ & $19.19 \%$ & $36.69 \%$ & $-1.06 \%$ & $2.38 \%$ & $9.95 \%$ & $2.60 \%$ & $0.32 \%$ & $-0.54 \%$ \\
\hline West & $15.28 \%$ & $25.06 \%$ & $24.50 \%$ & $42.59 \%$ & $3.12 \%$ & $3.49 \%$ & $49.97 \%$ & $2.47 \%$ & $0.41 \%$ & $0.61 \%$ \\
\hline South & $19.39 \%$ & $15.31 \%$ & $19.05 \%$ & $28.44 \%$ & $-0.07 \%$ & $2.52 \%$ & $18.53 \%$ & $2.39 \%$ & $0.49 \%$ & $-0.36 \%$ \\
\hline Total & $\begin{array}{l}100.00 \\
\%\end{array}$ & $25.22 \%$ & $\begin{array}{l}100.00 \\
\%\end{array}$ & $38.44 \%$ & $0.00 \%$ & $13.22 \%$ & $100.00 \%$ & $12.44 \%$ & $1.52 \%$ & $-0.07 \%$ \\
\hline Difference & & & & & & $13.22 \%$ & & & & \\
\hline Contribution & & & & & $0.00 \%$ & $100.00 \%$ & & $94.10 \%$ & $11.46 \%$ & $-0.55 \%$ \\
\hline
\end{tabular}

Sources: Treatment of EDSG 2000 and EDSG 2012 data, Gabon

Table 4. Simple and advanced decompositions of the increase in the proportion of overweight women by residential area (Cameroon).

\begin{tabular}{|c|c|c|c|c|c|c|c|c|c|c|}
\hline \multirow[b]{2}{*}{ residential Area } & \multicolumn{2}{|l|}{2004} & \multicolumn{2}{|l|}{2011} & \multicolumn{3}{|c|}{ Simple decomposition } & \multicolumn{3}{|c|}{ Advanced decomposition } \\
\hline & $\begin{array}{l}\% \\
\text { woman }\end{array}$ & $\begin{array}{l}\text { Rate of } \\
\text { obesity }\end{array}$ & $\begin{array}{l}\% \\
\text { woman }\end{array}$ & $\begin{array}{l}\text { Rate of } \\
\text { obesity }\end{array}$ & $\begin{array}{l}\text { Composition } \\
\text { effect }\end{array}$ & $\begin{array}{l}\text { Performance } \\
\text { effect }\end{array}$ & $\begin{array}{l}\text { contribution } \\
\text { by level }\end{array}$ & Base & Differentiation & Residual \\
\hline $\begin{array}{l}\text { Ext- North / North-east } \\
\text { / Adamaoua. }\end{array}$ & $25.61 \%$ & $14.92 \%$ & $28.84 \%$ & $14.25 \%$ & $0.47 \%$ & $-0.18 \%$ & $10.42 \%$ & $-0.37 \%$ & $0.47 \%$ & $-0.28 \%$ \\
\hline Ydé / Dla & $17.37 \%$ & $45.11 \%$ & $18.52 \%$ & $48.01 \%$ & $0.54 \%$ & $0.52 \%$ & $38.12 \%$ & $-0.25 \%$ & $0.62 \%$ & $0.15 \%$ \\
\hline $\begin{array}{l}\text { South / East / Central / } \\
\text { Littoral }\end{array}$ & $25.63 \%$ & $36.14 \%$ & $26.41 \%$ & $41.50 \%$ & $0.30 \%$ & $1.39 \%$ & $61.28 \%$ & $-0.36 \%$ & $1.35 \%$ & $0.40 \%$ \\
\hline East / West S / N West & $31.39 \%$ & $27.00 \%$ & $26.23 \%$ & $31.29 \%$ & $-1.50 \%$ & $1.24 \%$ & $-9.67 \%$ & $-0.39 \%$ & $1.99 \%$ & -0.36 \\
\hline Total & $100.00 \%$ & $29.40 \%$ & $100.00 \%$ & $32.17 \%$ & $0.00 \%$ & $2.77 \%$ & $100.00 \%$ & $-1.37 \%$ & $4.44 \%$ & $-0.10 \%$ \\
\hline Difference & & & & & & $2.77 \%$ & & & & \\
\hline Contribution & & & & & $0.00 \%$ & $100.00 \%$ & & $-49.46 \%$ & $160.14 \%$ & $-3.51 \%$ \\
\hline
\end{tabular}

Sources: Treatment of EDSG 2004 and EDS-MICS 2011 data, Cameroon.

\subsubsection{Educational Level}

In this study, educational level corresponds to the educational attainment which is given by the respondent at the time of investigation. Three educational levels are distinguished: "No education", "Primary" and "Secondary/higher» (Tables V and IV).

The simple decomposition of the increased number of 
obese women, according to educational level, highlights the predominance of performance effect in those countries: $69.56 \%$ in Cameroon and $98.00 \%$ in Gabon. We also observe that women, from "secondary/higher" education, have the highest contribution: $84.64 \%$ (in Gabon) and $125.66 \%$ in Cameroon.
The extension of performance's effect (Table V and VI) shows that the basic effect would be the main explanatory source of increasing in the proportion of obese women: approximately $69.31 \%$ in Cameroon and $142.81 \%$ in Gabon. The same observation was made in Cameroon

Table 5. Simple and advanced decompositions of the increase in the proportion of overweight women by educational level (Gabon).

\begin{tabular}{|c|c|c|c|c|c|c|c|c|c|c|}
\hline \multirow[b]{2}{*}{ Educational level } & \multicolumn{2}{|l|}{2000} & \multicolumn{2}{|l|}{2012} & \multicolumn{2}{|c|}{ Simple decomposition } & \multicolumn{4}{|c|}{ Advanced decomposition } \\
\hline & $\begin{array}{l}\% \\
\text { Woman } \\
\end{array}$ & $\begin{array}{l}\text { Rate of } \\
\text { obesity }\end{array}$ & $\begin{array}{l}\% \\
\text { Woman } \\
\end{array}$ & $\begin{array}{l}\text { Rate of } \\
\text { obesity }\end{array}$ & $\begin{array}{l}\text { Effect of } \\
\text { composition }\end{array}$ & $\begin{array}{l}\text { Effect of } \\
\text { performance }\end{array}$ & $\begin{array}{l}\text { contribution } \\
\text { by level }\end{array}$ & Base & Differentiation & Residual \\
\hline Primary & $47.15 \%$ & $23.98 \%$ & $34.77 \%$ & $36.60 \%$ & $-3.75 \%$ & $5.17 \%$ & $10.75 \%$ & $7.73 \%$ & $2.60 \%$ & $-5.16 \%$ \\
\hline Secondary and higher & $47.30 \%$ & $26.25 \%$ & $60.48 \%$ & $39.01 \%$ & $4.30 \%$ & $6.88 \%$ & $84.64 \%$ & $10.17 \%$ & $5.12 \%$ & $-8.42 \%$ \\
\hline Difference & & & & & & 13.22 & & & & \\
\hline Contribution & & & & & $2.00 \%$ & $98.00 \%$ & & $142.81 \%$ & $59.64 \%$ & $-104.57 \%$ \\
\hline
\end{tabular}

Sources: Treatment of EDSG 2000 and EDSG 2012 data, Gabon

Table 6. Simple and advanced decompositions of the increase in the proportion of overweight women by educational level (Cameroon).

\begin{tabular}{|c|c|c|c|c|c|c|c|c|c|c|}
\hline \multirow[b]{2}{*}{ educational level } & \multicolumn{2}{|l|}{2004} & \multicolumn{2}{|l|}{2011} & \multicolumn{3}{|c|}{ Simple decomposition } & \multicolumn{3}{|c|}{ Advanced decomposition } \\
\hline & $\begin{array}{l}\% \\
\text { Woman }\end{array}$ & $\begin{array}{l}\text { Rate of } \\
\text { obesity }\end{array}$ & $\begin{array}{l}\% \\
\text { Woman }\end{array}$ & $\begin{array}{l}\text { Rate of } \\
\text { obesity }\end{array}$ & $\begin{array}{l}\text { Effect of } \\
\text { composition }\end{array}$ & $\begin{array}{l}\text { Performance } \\
\text { effect }\end{array}$ & $\begin{array}{l}\text { contribution } \\
\text { by level }\end{array}$ & Base & Differentiation & Residual \\
\hline Without level & $19.69 \%$ & $13.82 \%$ & $17.14 \%$ & $15.77 \%$ & $-0.38 \%$ & $0.34 \%$ & $-1.37 \%$ & $0.35 \%$ & $0.00 \%$ & $-0.01 \%$ \\
\hline Primary & $40.94 \%$ & $30.27 \%$ & $36.25 \%$ & $32.33 \%$ & $-1.47 \%$ & $0.80 \%$ & $-24.29 \%$ & $0.74 \%$ & $-0.01 \%$ & $0.06 \%$ \\
\hline Secondary and higher & $39.37 \%$ & $36.23 \%$ & $46.61 \%$ & $38.07 \%$ & $2.69 \%$ & $0.79 \%$ & $125.66 \%$ & $0.83 \%$ & $-0.01 \%$ & $-0.02 \%$ \\
\hline total & $100.00 \%$ & $29.40 \%$ & $100.00 \%$ & $32.17 \%$ & $0.84 \%$ & $1.93 \%$ & $100.00 \%$ & $1.92 \%$ & $-0.02 \%$ & $-0.03 \%$ \\
\hline Contribution & & & & & $30.44 \%$ & $69.56 \%$ & & $69.31 \%$ & $-0.81 \%$ & $1.05 \%$ \\
\hline
\end{tabular}

Sources: Treatment of EDSG 2004 and EDS-MICS 2011 data, Cameroon

\subsubsection{Standard of Living of the Household}

The standard of living of the household (Tables VII and VIII) was measured by durable possession of household (roofing materials, floor, wall, source of water, type of toilet, and number of rooms in household ...). To successfully measure the standard of living for each country, we had to combine indicators of standards of living, from properties possessed by household in both urban and rural areas. This standard of living variable has three modalities: low, medium and high. The simple decomposition, describing the increase in the proportion of obese women, with respect to the standard of living in household, highlights an important contribution of performance's effect: $77.22 \%$ in Gabon and
$133.15 \%$ in Cameroon. The differential change in the of women's behavior living in households explains the increase in the proportion of obese women between 2000 and 2012 in Gabon, and between 2004 and 2011 in Cameroon. Women having an average standard of living (Gabon) and lower standard of living (Cameroon), contribute to this increase by $75.27 \%$ and $161.78 \%$ respectively. The extension of the performance effect (Table VII and VIII) shows that the basic effect contributes mainly to the predominance effect of performance in these two countries. In other words, the global change in the basic nutritional system, observed in Gabon and Cameroon, could be the main reason for the increase in the number of obese women.

Table 7. Increase in the proportion of overweight women by standard living in the household in Gabon: Simple and advanced decompositions.

\begin{tabular}{|c|c|c|c|c|c|c|c|c|c|c|}
\hline \multirow[b]{2}{*}{ Standard of living } & \multicolumn{2}{|l|}{2004} & \multicolumn{2}{|l|}{2012} & \multicolumn{2}{|c|}{ Simple decomposition } & \multicolumn{4}{|c|}{ Advanced decomposition } \\
\hline & $\%$ woman & $\begin{array}{l}\text { rate of } \\
\text { obesity }\end{array}$ & $\%$ woman & $\begin{array}{l}\text { rate of } \\
\text { obesity }\end{array}$ & $\begin{array}{l}\text { Effect of } \\
\text { composition }\end{array}$ & $\begin{array}{l}\text { Effect of } \\
\text { Performance }\end{array}$ & $\begin{array}{l}\text { contribution } \\
\text { by level }\end{array}$ & Base & Differentiation & Residual \\
\hline Low & $73.75 \%$ & $23.19 \%$ & $47.11 \%$ & $31.48 \%$ & $-7.28 \%$ & $5.01 \%$ & $3.40 \%$ & $5.02 \%$ & $0.76 \%$ & $-0.77 \%$ \\
\hline Average & $15.39 \%$ & $29.23 \%$ & $31.17 \%$ & $42.62 \%$ & $5.67 \%$ & $3.12 \%$ & $75.27 \%$ & $1.93 \%$ & $0.59 \%$ & $0.60 \%$ \\
\hline High & $10.86 \%$ & $36.30 \%$ & $21.72 \%$ & $47.12 \%$ & $4.53 \%$ & $1.76 \%$ & $21.34 \%$ & $1.35 \%$ & $0.62 \%$ & $-0.21 \%$ \\
\hline total & $100.00 \%$ & $25.54 \%$ & $100.00 \%$ & $38.35 \%$ & $2.92 \%$ & $9.89 \%$ & $100.00 \%$ & $8.31 \%$ & $1.96 \%$ & $-0.38 \%$ \\
\hline Difference & & & & & $12.81 \%$ & & & & & \\
\hline Contribution & & & & & $22.78 \%$ & $77.22 \%$ & & $64.87 \%$ & $15.33 \%$ & $-3.00 \%$ \\
\hline
\end{tabular}

Sources: Treatment of EDSG 2000 and EDSG 2012 data, Gabon 
Table 8. Increase in the proportion of overweight women by standard living in the household in Cameroon: simple and advanced decompositions effects.

\begin{tabular}{|c|c|c|c|c|c|c|c|c|c|c|}
\hline \multirow[b]{2}{*}{ Standard of living } & \multicolumn{2}{|l|}{2004} & \multicolumn{2}{|l|}{2011} & \multicolumn{2}{|c|}{ Simple decomposition } & \multirow[b]{2}{*}{$\begin{array}{l}\text { contribution } \\
\text { by level }\end{array}$} & \multicolumn{2}{|c|}{ Advanced decomposition } & \multirow[b]{2}{*}{ Residual } \\
\hline & \% Woman & $\begin{array}{l}\text { Rate of } \\
\text { obesity }\end{array}$ & $\begin{array}{l}\% \\
\text { Woman } \\
\end{array}$ & $\begin{array}{l}\text { Rate of } \\
\text { obesity }\end{array}$ & $\begin{array}{l}\text { Effect of } \\
\text { composition }\end{array}$ & $\begin{array}{l}\text { Effect of } \\
\text { performance }\end{array}$ & & Base & Differentiation & \\
\hline Low & $43.35 \%$ & $22.52 \%$ & $51.32 \%$ & $27.70 \%$ & $2.00 \%$ & $2.45 \%$ & $161.78 \%$ & $2.35 \%$ & $-0.46 \%$ & $0.56 \%$ \\
\hline Average & $19.91 \%$ & $31.41 \%$ & $18.03 \%$ & $32.05 \%$ & $-0.60 \%$ & $0.12 \%$ & $-17.26 \%$ & $0.94 \%$ & $-0.37 \%$ & $-0.45 \%$ \\
\hline High & $36.74 \%$ & $36.43 \%$ & $30.65 \%$ & $39.67 \%$ & $-2.32 \%$ & $1.09 \%$ & $-44.52 \%$ & $1.67 \%$ & $-0.98 \%$ & $0.40 \%$ \\
\hline Total & $100.00 \%$ & $29.40 \%$ & $100.00 \%$ & $32.15 \%$ & $-0.91 \%$ & $3.67 \%$ & $100.00 \%$ & $4.96 \%$ & $-1.81 \%$ & $0.51 \%$ \\
\hline Contribution & & & & & $-33.15 \%$ & $133.15 \%$ & & $180.36 \%$ & $-65,73 \%$ & $18.65 \%$ \\
\hline
\end{tabular}

Sources: Treatment of EDSG 2004 and EDS-MICS 2011 data, Cameroon

\subsubsection{Marital Status}

Marital status refers to the matrimonial status of the respondent at the time of survey. Three modalities are distinguished: "Single", "Union" and "Widow/divorced/ separated." The increase in the proportion of obese women, with respect to marital status, is mainly due to change of behavior: the effect of performance being $120.71 \%$ in Cameroon and $11887 \%$ in Gabon (Tables X and XI). The change of behavior of married women would be the primary reason for the increased in the number of obese women in Gabon (52.45\%) and Cameroon (48.25\%). Extension of the effect of performance reveals a predominance effect of differentiation: approximately $80.32 \%$ in Gabon and $104.01 \%$ in Cameroon. In other words, the differentiation of nutritional behavior, which is more pronounced among married women, could be the main explanation for the increased in the number of obese women in both countries.

Table 9. Increase in the proportion of overweight women by marital in Gabon: effects of simple and advanced decompositions.

\begin{tabular}{|c|c|c|c|c|c|c|c|c|c|c|}
\hline \multirow[b]{2}{*}{ marital status } & \multicolumn{2}{|l|}{2004} & \multicolumn{2}{|l|}{2011} & \multicolumn{2}{|c|}{ Simple decomposition } & \multirow[b]{2}{*}{$\begin{array}{l}\text { contribution } \\
\text { by level }\end{array}$} & \multicolumn{3}{|c|}{ Advanced decomposition } \\
\hline & \% Woman & $\begin{array}{l}\text { Rate of } \\
\text { obesity }\end{array}$ & $\begin{array}{l}\text { \% } \\
\text { Woman }\end{array}$ & $\begin{array}{l}\text { Rate of } \\
\text { obesity }\end{array}$ & $\begin{array}{l}\text { Effect of } \\
\text { composition }\end{array}$ & $\begin{array}{l}\text { Performance } \\
\text { effect }\end{array}$ & & Base & Differentiation & Residual \\
\hline Single & $19.46 \%$ & $13.42 \%$ & $32.46 \%$ & $22.36 \%$ & $2.33 \%$ & $2.32 \%$ & $35.16 \%$ & $0.69 \%$ & $1.50 \%$ & $-4.51 \%$ \\
\hline Union & $67.30 \%$ & $28.65 \%$ & $57.01 \%$ & $45.98 \%$ & $-3.84 \%$ & $10.77 \%$ & $52.45 \%$ & $1.29 \%$ & $5.61 \%$ & $-11.62 \%$ \\
\hline $\begin{array}{l}\text { Widow / divorced } \\
\text { separate }\end{array}$ & / $13.24 \%$ & $25.14 \%$ & $10.53 \%$ & $47.17 \%$ & $-0.98 \%$ & $2.62 \%$ & $12.40 \%$ & $0.54 \%$ & $3.50 \%$ & $2.49 \%$ \\
\hline Difference & & & & & & $13.22 \%$ & & & & \\
\hline Contribution & & & & & $-18.87 \%$ & $118.87 \%$ & & $19.04 \%$ & $80.32 \%$ & $-103.18 \%$ \\
\hline
\end{tabular}

Source: EDSG 2000 and EDSG 2012

Table 10. Increase in the proportion of overweight women by marital status in Cameroon: effects of simple and advanced decompositions.

\begin{tabular}{|c|c|c|c|c|c|c|c|c|c|c|c|}
\hline \multirow{2}{*}{\multicolumn{2}{|c|}{ Marital status }} & \multicolumn{2}{|l|}{2004} & \multicolumn{2}{|l|}{2011} & \multicolumn{2}{|c|}{ Simple decomposition } & \multicolumn{4}{|c|}{ Advanced decomposition } \\
\hline & & \% Woman & $\begin{array}{l}\text { Rate of } \\
\text { obesity }\end{array}$ & \% Woman & $\begin{array}{l}\text { Rate of } \\
\text { obesity }\end{array}$ & $\begin{array}{l}\text { Effect of } \\
\text { composition }\end{array}$ & $\begin{array}{l}\text { Effect of } \\
\text { performance }\end{array}$ & $\begin{array}{l}\text { Contribution } \\
\text { by level }\end{array}$ & Base & Differentiation & Residual \\
\hline Single & & $22.66 \%$ & $21.12 \%$ & $27.34 \%$ & $21.67 \%$ & $1.00 \%$ & $0.14 \%$ & $41.18 \%$ & $-0.07 \%$ & $0.39 \%$ & $-0.19 \%$ \\
\hline Union & & $68.81 \%$ & $31.42 \%$ & $64.19 \%$ & $35.76 \%$ & $-1.55 \%$ & $2.89 \%$ & $48.25 \%$ & $-0.19 \%$ & $2.09 \%$ & $0.98 \%$ \\
\hline $\begin{array}{l}\text { Separate } \\
\text { divorced / }\end{array}$ & widow/ & $8.53 \%$ & $35.07 \%$ & $8.47 \%$ & $38.77 \%$ & $-0.02 \%$ & $0.31 \%$ & $10.57 \%$ & $-0.02 \%$ & $0.40 \%$ & $-0.06 \%$ \\
\hline Total & & $100.00 \%$ & $29.40 \%$ & $100.00 \%$ & $32.17 \%$ & $-0.57 \%$ & $3.34 \%$ & $100.00 \%$ & $-0.28 \%$ & $2.88 \%$ & $0.74 \%$ \\
\hline Difference & & & & & & & $2.77 \%$ & & & & \\
\hline Contribution & & & & & & $-20.71 \%$ & $120.71 \%$ & & $-10.11 \%$ & $104.01 \%$ & $26.61 \%$ \\
\hline
\end{tabular}

Source: EDSG 2004 and EDS-MICS 2011

\subsection{Effects of Some Factors That Explain the Overweight Women Condition in Cameroon (2011) and Gabon (2012)}

The binary logistic regression model considered obese women as the dependent variable. It takes the value one (1) if the woman has a BMI greater than or equal to $25 \mathrm{~kg} / \mathrm{m} 2$ and zero (0) if otherwise (Table XI). Explanatory variables included in the analysis are: residential area, age group, place of residence, standard of living of household, marital status, occupation, number of children, religion and educational level. This study had 5\% significance threshold. Therefore, with a marginal error of 5\%, residential area, age group, place of residence, standard of living of household, 
marital status, occupation, number of children and educational level(only in Cameroon) variables contribute to explain the increase in the proportion of obese women in both countries.

Concerning residential area, it is established that in Cameroon, women living in "Yaoundé /Douala", "West / Northwest / Southwest" and "center / Littoral / South / East " regions are 2.97, 3.92 and 2.05 times more likely to be obese respectively as compared to those living in " Adamawa / Far North / Northeast " regions. In Gabon, we have observed that women who live in the North (Ogoou, Ivindo and Woleu-ntem) and South (Nguni, Nyanga) are $21.0 \%$ and $40.7 \%$ less likely to be obese respectively as compared to those living in the cities of Libreville and Port-Gentil.

The results in Table XI also highlight that the risk for a woman to become obese, increases with age. Thus, we observe that Cameroonians between the ages 25-34 and 35-49 years are 1.86 and 3.22 times more likely to become obese respectively as compared to those in the 15-19 years cohort. The same observation was made in Gabon. Women aged 25-34 and 35-49 years are 2.26 and 4.29 times more likely to become obese respectively as compared to those in the $15-19$ years cohort.

Talking about area of residence, it is established that women living in rural areas are less likely to be obese compared to those who live in urban areas. The Table XI shows that in Cameroon and Gabon, the women, residing in rural areas, are $44.80 \%$ and $23.33 \%$ less likely to be overweight respectively as compared to those living in urban areas.

Concerning the standard of living in the household, we note that the women, living in households with higher standard of living, have the greatest risk to be obese. We observed in Cameroon that women, who live in households with an average or a higher standard of living, are 1.37 and 1.65 times more likely to be obese respectively as compared to those living in household with a lower standard of living.
This observation was equally made in Gabon, where we noted that; women living in households with average or high standard of living are 1.37 and 1.65 times more likely to be overweight respectively as compared to those who are living in households with low standard of living.

Marital status has a significant influence on obesity. It appears that women with other marital status than single are more likely to be overweight. This is the case in Cameroon where it is established that married women or separated / widowed / divorced are 1.74 and 1.88 times (1.37 times and 1.65 times) more likely to be obese respectively as compared to those who are single.

Occupational status significantly influences weight. We observed in Cameroon that administrators and the unemployed were 1.76 and 1.88 times more likely to be obese respectively as compared to farmers, laborers or those in the armed force. In Gabon for example, female administrators are 1.73 times more likely to be obese and those who are unemployed are1.49 times more likely to be obese.

The Total number of children was significantly associated with obesity. The tendency of having at least a child increases the risk to become obese in both countries. The results showed that, women who have had at least one child are approximately 1.47 and 1.45 times more likely to be overweight in both countries respectively as compared to those who had never had a child.

In Cameroon, we noticed that the educational level influences women's weight. We observed that higher educational level presented the highest risk for women. The higher the educational level, the higher the risk of becoming obese in central Africa; which is a paradox! It is established that women, who have primary or at least secondary educational level, are 1.47 and 1.81 times more likely to be overweight respectively as compared to those who have no education.

Table 11. Binary logistic model explaining women overweight.

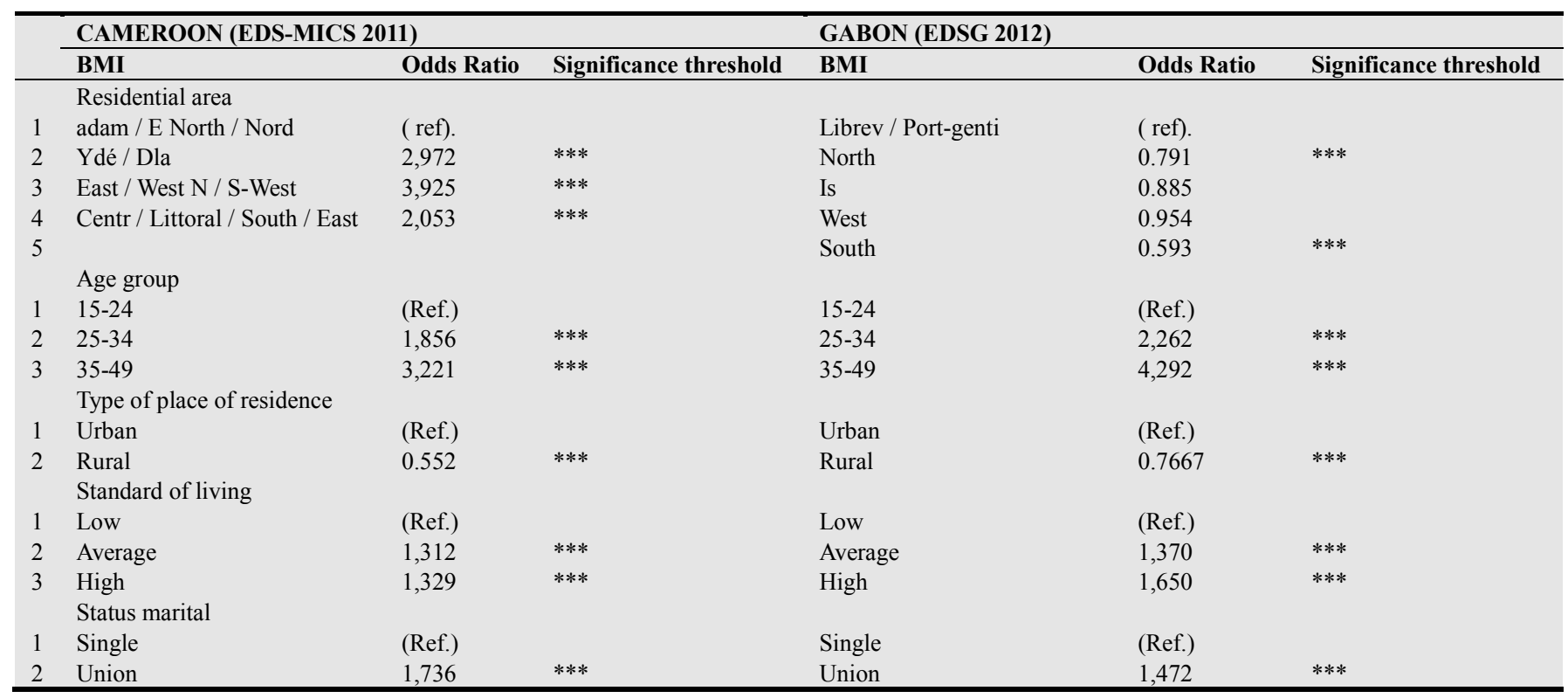




\begin{tabular}{|c|c|c|c|c|c|c|}
\hline & \multicolumn{3}{|c|}{ CAMEROON (EDS-MICS 2011) } & \multicolumn{3}{|l|}{ GABON (EDSG 2012) } \\
\hline & BMI & Odds Ratio & Significance threshold & BMI & Odds Ratio & Significance threshold \\
\hline 3 & $\begin{array}{l}\text { Separated / Widow / } \\
\text { Divorced } \\
\text { Occupation status }\end{array}$ & 1,877 & $* * *$ & $\begin{array}{l}\text { Separated / Widow / } \\
\text { Divorced }\end{array}$ & 1,332 & $* * *$ \\
\hline 1 & Agricult / worker / armed & (Ref.) & & Agricult / worker / armed & (Ref.) & \\
\hline 2 & Administration & 1,763 & $* * *$ & Administration & 1,734 & $* * *$ \\
\hline 3 & $\begin{array}{l}\text { unemployment } \\
\text { Total children ever born }\end{array}$ & 1,877 & $* * *$ & unemployment & 1,486 & $* * *$ \\
\hline 1 & No child & (Ref.) & & childless & (Ref.) & \\
\hline 2 & 1 or 2 & 1,425 & $* * *$ & 1 or 2 & 1,512 & $* * *$ \\
\hline 3 & 3 or 4 & 1,539 & $* * *$ & 3 or 4 & 1,365 & $* * *$ \\
\hline 4 & $\begin{array}{l}\text { More than } 4 \\
\text { Father's religion }\end{array}$ & 1,443 & $* * *$ & More than 4 & 1,478 & $* * *$ \\
\hline 1 & Catholic & (Ref.) & & Catholic & (Ref.) & \\
\hline 2 & Muslim & 1,192 & & Muslim & 1,761 & \\
\hline 3 & Animistic & 0.814 & & Animistic & 0.763 & \\
\hline 4 & Other & 0.669 & & Other & 0.467 & \\
\hline 5 & $\begin{array}{l}\text { Protestant } \\
\text { Educational level of father }\end{array}$ & 0.960 & & Protestant & 0,985 & \\
\hline 1 & No education & (Ref.) & & No education & (Ref.) & \\
\hline 2 & Primary & 1,472 & $* * *$ & Primary & 1,016 & \\
\hline 3 & Secondary and higher & 1,810 & $* * *$ & Secondary and higher & 1,202 & \\
\hline \multicolumn{4}{|c|}{$\begin{array}{l}\text { Sources: Treatment of EDS-MICS } 2011 \text { data, Cameroon } \\
\text { Significance threshold: *** }(1 \%) * *(5 \%) *(10 \%) \\
\text { (Ref.) reference }\end{array}$} & \multicolumn{3}{|c|}{ Sources: Treatment of EDSG 2012 data, Gabon } \\
\hline
\end{tabular}

Significance threshold: *** (1\%)** $(5 \%) *(10 \%)$

(Ref.) reference

\section{Discussion}

Generally, it is established that the female population has minor influence on the increase in the proportion of obese women between 2004-2011 (Cameroon) and 2000-2012 (Gabon). This increase can be mainly attributed to the change of nutritional behavior among women. The change observed is more noticeable in women above 35 years of age. This can be explained firstly, by the events that mark the reproductive process of a woman: pregnancy, childbirth, hormonal contraceptives, etc. In addition, it is worth noting that nearly $21 \%$ of births occur, after short reproductive intervals (less than 24 months) and the number of children per woman is estimated at 5.1 in Cameroon. [8] This estimate is not different from that of Gabon, as each woman gives birth to an average of 4.1 children [3]. Thus, a large number of children associated to short birth intervals, promote conservation of adipose tissues and increase weight during pregnancy especially for women with very low physical activities. Secondly, the tight relationship existing between age and increase in the prevalence of overweight can justify the increase in the number of obese women during reproductive age. [9] In fact, the feeling of satiety disappears as women advance in age, due to degeneration which could lead to the excessive weight gain [13]. In Cameroon, only $3.20 \%$ of women are engaged in regular physical activities [8]. This sedentary condition and lack of physical exercises affect many women who share "secondary or higher" educational level, and performing other activities that requires little physical effort. Due to their occupational status, they are predisposed to adopt new eating habits (nibbling between meals, meals at irregular intervals, ...) associated with new life styles which contribute to reduce physical activities (using a car for short distances, long hours spent sitting in front of a computer or TV screen).

The number of obese women is higher in cities of both countries. In Cameroon, we notice that women, specifically those living in "West / northwest / southwest" regions are more likely to be obese. This can be explained by the abundance of food and the level of geographical development in these areas. The majority of dishes in these regions are very rich in fat (Okok, Koki, "military uniform" pork meat...) and are very poor in complex carbohydrates which are good for digestion. In the case of big cities, we find a great number of national administrative offices, as compared to the "West / Northwest / Southwest» region (Cameroon) where agricultural activities are predominant: we equally noticed an increase in sedentary as well as low physical activities life style among women in both countries [8].

Women with high standard of living and those living with their spouse (union) are more likely to gain weight. This can be explained by the presence of a certain ease in terms of societal criteria of wellbeing and beauty, as well as the characteristics of social stability. In both countries, obesity is a sign of well-being and beauty. For a married woman, being classified as a normal or lean woman (BMI normal or below $18.5 \mathrm{~kg} / \mathrm{m} \mathrm{2}$ ) suggests that the spouse is not taking good care of her or that she might be suffering from a lack of intimacy in her relationship.

Similarly, women who have a low standard of living will tend to gain weight when their economic condition improves. This weight gain is regarded as an outward sign of internal wellbeing. Conclusively, all these societal considerations can justify the obese conditions observed in both Cameroon and 
Gabon.

From the results above, we make the following recommendations:

- Raise awareness about the importance of a healthy diet: eat much organic foods such fruits and vegetables;

- Encourage sport/physical activities which promote muscle building and burning of excess calories;

- Encourage couples to enrol into family planning programs to permit birth spacing.

This study had some limitations. The first is related to the fact that we mainly rely on secondary data (EDS-MICS, 2011; EDSC, 2004; EDSG 2000 and EDSG 2012). And the second is about our study population only on women of child bearing age (15-49 years). However, these difficulties have little impact on the quality of results. In addition, it would have been interesting if data on men were available to better appreciate the trends of overweight by gender in both Cameroon and Gabon.

\section{Conclusion}

The purpose of this study was to understand the explanatory sources of the increase in the number of obese women during 2004-2011 (Cameroon) and 2000-2012 (Gabon); and to identify the factors which explain the trends of obesity in 2011 (Cameroon) 2012 (Gabon). After the analyses, we noted that the increase in the proportion of obese women, that is $2.77 \%$ in Cameroon between 2004 and 2011, and 13.22\% in Gabon between 2000 and 2012, is mainly due to a change in the life style of women. This change differs according to socio-cultural, economic and demographic characteristics of the women population. In addition, it was observed that depending on the residential areas, age group, place of residence, standard of living in of household, marital status, occupation and educational level (only for Cameroon), women have differential risks of becoming obese. Thus, a woman with a higher standard of living has the greatest risk to become obese. Furthermore, as the woman ages accompanied by low physical activities which help to burn calories, women from both countries have high chances of becoming obese. We must finally mention the effect of modernization and technological development which has increased sedentary life styles especially among the women population in urban areas and big cities. All in all, it is important to promote healthy dietary habits and regular physical exercises among women from both Cameroon and Gabon. Actors of this sensitization process should be professional of health and educational domain, in partnership with political and opinion leaders.

\section{References}

[1] Basdevant A., Guy-Grand B. (2004). Médecine de l'obésité. Flammarion Médecine-Sciences, 245 p

[2] Basdevant, A., Laville, M., Lerebours, E. (2001). Traité de nutrition clinique de l'adulte, Flammarion Médecine-Sciences, $350 \mathrm{p}$.

[3] Direction Générale de la Statistique (DGS) et ICF International (2013). Enquête Démographique et de Santé du Gabon 2012. Calverton, Maryland et Libreville, Gabon : DGS ICF International

[4] Direction Générale de la Statistique et des Etudes Economiques (DGSEE)[Gabon] et ORC Maroc. 2001. Enquête Démographique et de Santé du Gabon 2000. Calverton, Maryland : Direction Générale de la Statistique et des Etudes Economiques, et Fonds des Nations Unies pour la Population et ORC Macro.

[5] Eloundou-Enyegue PM, Stokes CS. (2007). Demographic Transitions and Children's Resources: Growth or Divergence? Demographic Research 16 (7): 195-218.

[6] Institut National de la Statistique (INS) (2008). Condition de vie des populations et profil de pauvreté au Cameroun en 2007. Rapport principal de l'ECAM3, Yaoundé, Cameroun, 263 p.

[7] Institut National de la Statistique (2004). Enquête Démographique et de Santé du Cameroun. Calverton, Maryland, USA: INS et ORC Macro.

[8] Institut National de la Statistique (INS) et ORC Macro. (2011). Enquête Démographique et de Santé du Cameroun. Calverton, Maryland, USA: INS et ORC Macro.

[9] Ob Epi-Roche. (2009) Enquête épidémiologique nationale sur le surpoids et l'obésité.

[10] Oliver I., Jouret B., Tauber M. (2006). Toulouse Midi-Pyrénées : réseau ville-hôpital de prévention et prise en charge de l'obésité pédiatrique. Obésité 1(2-4), 69-71.

[11] OMS. (1997). Obésité : prévention et prise en charge de l'épidémie mondiale ; rapport d'une consultation de l'OMS. Série Rapports Techniques 894, 117 p.

[12] Poulain J.-P. (2009). Sociologie de l'obésité, Presses Universitaires de France, $310 \mathrm{p}$.

[13] Taramasco Toro C. A.(2011). Impact de l'obésité sur les structures sociales et impact des structures sociales sur l'obésité : Facteurs individuels et environnementaux, Thèse de Doctorat, Université J. Fourier Grenoble, 430 p. 